\title{
Konseling kelompok dengan strategi self management untuk mengurangi perilaku agresif pada remaja
}

Defi Astriani, UniversitasMuhammadiyah Malang, Malang, Indonesia

Korespondonesi:

Defi Astriani, UniversitasMuhammadiyah Malang, Malang, email: defi45astriani@gmail.com

\author{
Riwayat artikel \\ Naskah diterima: \\ 07/11/2018 \\ Revisi diterima: \\ 02/12/2018 \\ Naskah disetujui: \\ $12 / 12 / 2018$
}

\begin{abstract}
Abstrak
Subjek adalah laki-laki yang saat ini duduk di bangku SMP. Para subjek mempunyai permasalahan terkait agresivitas. Perilaku yang ditunjukkan oleh kelima subjek adalah akibat dari melihat atau meniru apa yang ada dilingkungan keluarga dan teman sebaya. Mereka tinggal di lingkungan keluarga yang kurang adanya perhatian (broken home dan pola asuh yang salah) dan lingkungan pertemanan yang memberikan dampak negatif kepada subjek. Berdasarkan hasil asesmen wawancara, observasi, CFIT dan skala agresif, subjek didiagnosa mengalami permasalahan perilaku agresif. Intervensi bertujuan untuk mengurangi perilaku agresif subjek melalui konseling kelompok dengan tekhnik self management. adanya penurunan skor perilaku agresif pada siswa antara sebelum dan sesudah diberikan perlakuan konseling kelompok dengan menggunakan strategi self-management. Dan terdapat penurunan perilaku agresif berdasarkan pengamatan menggunakan indikator observasi yang telah dibuat.

Kata kunci: Self management, perilaku agresif, remaja, intervensi
\end{abstract}

\section{Latar Belakang}

Calhoun dan Acocella (Sobur, 2003) agresif adalah penggunaan hak sendiri dengan cara melanggar hak orang lain. Menurut Hurlock (2003) bahwa yang dimaksud perilaku agresif adalah tindakan permusuhan yang nyata atau ancaman permusuhan, biasanya tidak ditimbulkan oleh orang lain, diekspresikan berupa penyerangan secara fisik atau lisan terhadap pihak lain.

Perilaku Agresif dapat diartikan sebagai bentuk perilaku yang dimaksudkan untuk menyakiti seseorang baik secara fisik maupun mental. Selain itu perilaku agresif juga termasuk dalam perasaan negatif yang ditimbulkan oleh suatu tekanan yang dapat menghasilkan kecenderungan amarah (Sobur, 2003). Konsep mengenai perilaku agresif secara umum disampaikan oleh Clerq (1994) bahwa perilaku agresif adalah seseorang yang membahayakan, menyakiti, atau 
melukai orang lain. Menurut Krahe (2005) perilaku agresif adalah segala bentuk perilaku yang dimaksudkan untuk menyakiti atau melukai makhluk hidup lain yang tidak menginginkan datangnya perilaku. Menurut Krishnaveni \& Shahin (2014) perilaku agresif adalah sebuah perilaku yang memiliki tujuan yang sama yaitu menyakiti atau menciderai lawan.

Terdapat beberapa faktor yang mempengaruhi munculnya perilaku agresif, yaitu faktor amarah, faktor biologis, kesenjangan generasi atau adanya gap antara anak dengan orang tua yang dapat terlihat dalam bentuk hubungan komunikasi yang semakin minimal dan seringkali tidak nyambung, faktor lingkungan, modelling, dan faktor frustasi (Krahe, 2005). Agresif dapat dikelompok menjadi beberapa jenis. Buss \& Perry (1992) mengelompokkan agresivitas dalam tiga jenis yaitu: agresi fisik (memukul, menendang, menusuk, membakar), agresi verbal (mengumpat, membentak, berdebat, mengejek), agresi tidak langsung (membenci orang lain) dan permusuhan (perasaan ingin menyakiti orang lain).

Para subjek mengalami permasalahan yang sama yaitu ketika berada disekolah menunjukkan perilaku sering celometan (berkata tidak sopan kepada guru ketika pelajaran), mengejek, memanggil teman dengan nama julukan, memaki teman, berkata kotor, menjahili teman, dan merebut barang milik temannya.

Santrock (2003) menyebutkan salah satu faktor yang mempengaruhi agresivitas adalah kontrol diri. Sehubungan dengan pernyataan tersebut, Gunarsa (2004) menyebutkan bahwa salah satu dasar bagi remaja untuk berkembang secara normal adalah memiliki konsep diri yang baik. Hurlock (1980) mengatakan bahwa kontrol diri muncul karena adanya perbedaaan dalam mengelola emosi, cara mengatasi masalah, tinggi rendahnya motivasi, dan kemampuan mengelola potensi dan pengembangan kompetensinya. Kontrol diri sendiri berkaitan dengan bagaimana individu mampu mengendalikan emosi serta dorongan-dorongan dalam dirinya.

Sears, dkk. (1988) menyatakan bahwa perilaku biasanya merupakan reaksi yang dipelajari karena adanya penguat atau reinforcement. Perilaku dapat terbentuk karena pembelajaran melalui imbalan dan ganjaran. Jika efek perilaku adalah negatif maka dapat menurunkan perilaku tersebut. Perilaku agresi dapat menimbulkan efek yang negatif maka dengan pelatihan yang diberikan diharapkan dapat menurunkan perilaku agresi pada anak dengan penerapan metode imbalan atau ganjaran baik dengan verbal maupun non-verbal sebagai penguat untuk menurunkan perilaku agresi.

Perilaku yang ditunjukkan oleh keenam subjek adalah akibat dari melihat atau meniru apa yang ada dilingkungan keluarga dan teman sebaya. Mereka tinggal di lingkungan keluarga yang kurang adanya perhatian dan lingkungan pertemanan yang memberikan dampak negatif kepada subjek. Kemudian perilaku mereka mendapatkan penguatan berupa kepuasan karena bisa meluapkan emosi. Kondisi lingkungan sekitar subjek sangat berpengaruh pada perilaku subjek saat ini. Hal ini menunjukkan kurangnya kemampuan subjek dalam melakukan manajemen diri atau kontrol diri untuk mengendalikan emosi serta dorongan-dorongan dalam dirinya sehingga intervensi self management diperlukan untuk mengatasi hal tersebut.

Self management dalam beberapa penelitian sebelumnya ditemukan sebagai salah satu teknik yang efektif untuk mengurangi perilaku agresif pada remaja Denson, (DeWall \& Finkel, 2012 \& Baker., et al. 2016) Oleh karena itu, berdasarkan permasalahan yang dialami oleh keenam subjek, maka intervensi yang dilakukan untuk menanganinya adalah menggunakan self management.

\section{Metode Asesmen}

Asesmen untuk penegakan diganosa yang tepat dilakukan melalui serangkaian metode antara lain wawancara, observasi dan tes psikologi. Wawancara dilakukan terhadap subjek untuk memperoleh informasi lebih mendalam tentang permasalahan yang subjek alami. Observasi dilakukan untuk memperoleh informasi perilaku dan aktivitas subjek selama di sekolah. 
Tes psikologis yang digunakan adalah tes CFIT. Tes ini digunakan untuk melihat kapasitas intelektual subjek dan untuk melihat apakah intervensi yang diberikan bisa efektif. Sedangkan skala agresif digunakan untuk melihat tingkat perilaku agresif subjek.

\section{Presentasi Kasus}

Subjek A Subjek A merupakan seorang laki-laki berusia 13 tahun. Ia adalah anak tunggal. Ibu subjek baru saja meninggal beberapa bulan yang lalu. Sehingga saat ini ia hanya tinggal bersama dengan ayahnya. Ayah subjek bekerja sebagai pedagang. Setiap malam ayah subjek berjualan nasi goreng di warung miliknya yang lokasinya tidak jauh dari rumah. karena subjek adalah anak tunggal, maka sang ayah selalu menuruti apa yang menjadi kemauan subjek sehingga membuat subjek menjadi anak yang manja.

Subjek tinggal di lingkungan yang bisa dikatakan kurang sehat. Dimana sebagian besar yang tinggal di sana adalah remaja-remaja yang putus sekolah dan ia juga memiliki om yang juga mempunyai perilaku tidak sehat. Hal ini kemudian membuat subjek melihat dan meniru apa yang ada di lingkungan tempat tinggalnya dan berpengaruh pada perilaku subjek saat ini yaitu agresif. Salah satu perilaku agresif subjek adalah sering menjaili teman. Hal ini ia lakukan setiap hari kepada teman-temannya, terlebih pada anak yang lebih pendiam dan inferior dibandingkan dia.

Selain itu, subjek sering merokok, tidak mau mengerjakan tugas, dan membolos. Dalam sehari, ia bisa menghabiskan 3-5 batang rokok. Dan seminggu bisa membolos sebanyak 2-3 kali. Kegiatan yang dilakukan oleh subjek ketika membolos adalah bermain dengan teman-teman seusianya yang putus sekolah. Mereka sering menghabiskan waktu dengan merokok bersama, bermain game atau hanya sekedar mengelilingi kota Malang dengan sepeda motor.

Agresif verbal atau berkata kasar kepada teman juga sering dilakukan oleh subjek. Faktor yang melatarbelakangi melakukan agresif verbal ini biasanya diprovokasi terlebih dahulu oleh orang lain, selain itu disebabkan karena kebiasaan. Karena subjek sudah terbiasa ngomong kasar dari kecil, dan tidak segera ditangani sampai dewasapun akan tetap melakukan agresif verbal serta adanya faktor lingkungan yang mempengaruhi agresif verbal. Apalagi subjek tinggaldi lingkungan rumah yang mayoritas remaja-remaja putus sekolah dan kurang adanya pengawasan dari orang tua sehingga menjadikan subjek mengembangkan perilaku tersebut. Akibat dari perilakunya ini, subjek sering dihukum dan masuk ruang BK. Namun meskipun demikian tidak menimbulkan efek jera pada subjek.

Subjek B Subjek B merupakan seorang laki-laki berusia 14 tahun. Ia adalah anak kedua dari tiga bersaudara. Ia tinggal bersama kedua orang tua, kakak laki-laki dan adik perempuannya. Ibu subjek bekerja sebagai ibu rumah tangga sedangkan ayah subjek bekerja sebagai montir di luar kota.

Subjek tinggal dikeluarga dengan pola asuh otoriter. Dimana ayah subjek mendidik subjek dengan sangat keras dan tidak segan untuk memukul ketika subjek mempunyai kesalahan. Hal tersebut kemudian membuat subjek menjadi takut untuk membagikan atau sharing masalah yang ia alami ke keluarga terlebih dengan ayah. Emosi yang ia pendam kemudian ia lampiaskan di sekolah, yaitu dengan cara menjahili teman-temannya.

Subjek tergolong orang yang banyak berbicara dan cerewet sehingga kontrol perilaku yang ia lakukan sangat minim. subjek adalah individu yang mundah terpancing emosinya. Di sekolah ia sering usil, berbohong dan mengambil pulpen teman sekelas. Namun perilaku ia yang seperti ini hanya dilakukan kepada teman-temannya yang lebih lemah dan pada beberapa teman perempuannya. Sama seperti subjek A, subjek B juga sering keluar masuk ruangan BK karena membolos dan perilakunya yang lain seperti merokok di sekolah.

Subjek C Subjek C adalah seorang laki-laki berusia 15 tahun. Ia anak pertama dari dua bersaudara. Subjek tinggal bersama kedua orang tuanya dan adik perempuannya. Ibu subjek 
bekerja sebagai buruh harian, sedangkan ayah bekerja sebagai karyawan di sebuah pabrik. Dalam kesehariannya subjek mengaku sering membantu ibunya untuk menjaga adiknya ketika sang ibu pergi untuk bekerja.

Dibandingkan dengan subjek yang lain, subjek $\mathrm{C}$ tergolong orang yang kalem, lebih bisa untuk diarahkan dan penurut. Dulunya subjek $\mathrm{C}$ adalah korban bully dari teman-temannya yang lain. Karena merasa sering dibully, akhirnya dia menjadi mengikuti perilaku buruk temannya agar diakui oleh mereka dan tidak dibully lagi. Hal tersebut kemudian membuatnya menjadi sering membolos, merokok dan ikut-ikutan menjahili dan berkata kasar kepada teman. Dalam seminggu subjek membolos 1-2 kal, dan dalam sehari bisa merokok sebanyak 2-3 batang.

Agresif verbal yang dilakukannya pun jarang dibandingkan teman-temannya. Menurutnya agresif verbal yang terkadang dilakukannya dilatarbelakangi oleh suatu hal yang dialami tidak sesuai dengan yang diharapkan, namun ketika sudah berkumpul dengan teman-temannya, agresif verbal dan jahil menjadi bentuk candaan semata, agar akrab, tidak ada maksud untuk marah atau mengumpat kepada teman serta membuat suasana menjadi cair dan agar tidak di bully lagi.

Subjek D Subjek D adalah seorang laki-laki berusia 14 tahun. Ia anak keempat dari empat bersaudara. Subjek tinggal bersama kedua orang tuanya dan ketiga saudaranya. Ibu subjek bekerja sebagai ibu rumah tangga, sedangkan ayah bekerja sebagai buruh di sebuah pabrik.

Subjek tergolong remaja yang cerewet dan ceplas-ceplos dalam kesehariannya. Hal tersebut terlihat dalam proses asesmen maupun intervensi yang telah dilakukan kepadanya. Subjek mengatakan bahwa menjahili teman, berkata kasar, membolos sekolah, merokok, dan melanggar peraturan sekolah merupakan perilaku yang sering ia lakukan. Dalam seminggu subjek membolos sebanyak 1-2 kali dan merokok sebanyak 2-4 batang setiap harinya. Perilaku yang dilakukan oleh subjek kemudian membuatnya sering dipanggil guru dan masuk ruang BK untuk mendapatkan hukuman.

Subjek melakukan perilaku tersebut karena dilatar belakangi oleh kebiasaan dan lingkungan. Teman-teman di sekolah pun sering melakukan hal yang sama dengan subjek, sehingga membuat subjek sering terbawa perilaku tersebut dalam keehariannya terlebih ketika berada di sekolah. Karena subjek merupkan orang yang banyak bicara, dia sering ceplas-ceplos dalam mengucapkan agresif verbal jadi ketika berbincang atau berkumpul dengan teman-temannya subjek sering mengucapkannya sebagai bentuk guyonan bahkan bukan karena suatu provokasi.

Subjek E Subjek adalah seorang laki-laki berusia 15 tahun. Ia adalah anak tunggal. Orang tua subjek bercerai semenjak ia masih kecil. Ayah subjek tinggal di Jakarta dan membuatnya tidak bisa lagi bertemu dengan sang ayah. Ketika orang tua bercerai, subjek tinggal bersama ibu, kakek, dan neneknya. Namun saat ini subjek hanya tinggal bersama dengan kakek dan neneknya karena ibu subjek telah meninggal dunia akibat sakit jantung yang telah lama dideritanya.

Di rumah subjek kurang mendapatkan kasih sayang dari orang tuanya. Ditinggal ayahnya dari kecil dan tinggal dengan ibunya yang sudah lama sakit, membuat subjek kesulitan untuk mengungkapkan atau menyampaikan keluh kesah yang dialaminya. Hal ini kemudian membuat subjek mencari pelarian, yaitu dengan mencari teman yang dianggapnya mampu melupakan semua masalah yang dialaminya dan bisa dijadikan sebagai tempat untuk meluapkan emosinya. Dan akhirnya subjek berteman dengan lingkungan yang salah dan memberikan akibat pada perilakunya saat ini.

Subjek sering membolos, merokok, menjahili teman, berkata kasar dan berani kepada guru. Sebelum sekolah di SMP 15, subjek pernah bersekolah di SMP Lab. Namun karena subjek pernah membuat salah satu gurunya menangis dan sudah membuat berbagai kesalahan di sekolahnya, membuatnya di DO dari sekolah tersebut. Bukannya berubah menjadi baik, namun di SMP 15 ia tetap berperilaku yang sama. 
Setiap minggunya subjek membolos sebanyak 2-3 kali dan merokok 4-5 batang dalam sehari. Selain itu ia juga sering membuat ulah di sekolah. Perilaku yang dilakukan oleh subjek membuatnya sering mendapatkan teguran dan hukuman oleh guru.

Dollard menyatakan bahwa perilaku agresif adalah tanggapan emosi tak terkendali yang mengakibatkan timbulnya perilaku yang merusak, menyerang dan melukai. Tindakan ini dapat ditujukan pada orang lain, lingkungan maupun diri sendiri yang disebabkan oleh frustasi yang mendalam dan kekecewaan yang terjadi pada diri individu (Koeswara, 1988). Agresi merupakan perilaku yang dimaksudkan menyakiti orang lain, baik secara fisik maupun psikis. Jika menyakiti orang lain karena unsur ketidaksengajaan, maka perilaku tersebut bukan dikategorikan perilaku agresi. Rasa sakit akibat tindakan medis misalnya, walaupun sengaja dilakukan bukan termasuk agresi. Sebaliknya, niat menyakiti orang lain tetapi tidak berhasil, hal ini dapat dikatakan sebagai perilaku agresi (Baron \& Byrne, 1994).

Menurut Atkinson (2001), Perilaku agresif adalah perilaku untuk melukai orang lain (secara fisik atau verbal) atau merusak harta benda. Menurut Soemantri (2006) menjelaskan, bahwa perilaku agresif merupakan tindakan nyata dan mengancam sebagai ungkapan benci. Krahe (2005) mendefinisikan bahwa perilaku agresif verbal adalah berbohong, mengumpat atau memperburuk-burukkan orang lain, memberi nama julukan, memperolok-olok, bergunjing, mengejek, menghina atau menyindir, mencaci, mencela, dan mendamprat. Perilaku agresi dalam berbagai bentuk penyerangan baik fisik maupun verbal dan tindakan kriminal seringkali diikuti oleh beberapa faktor salah satunya dengan rendahnya kontrol diri yang dimiliki oleh seseorang.

Terdapat beberapa faktor yang mempengaruhi munculnya perilaku agresif, yaitu faktor amarah, faktor biologis, kesenjangan generasi atau adanya gap antara anak dengan orang tua yang dapat terlihat dalam bentuk hubungan komunikasi yang semakin minimal dan seringkali tidak nyambung, faktor lingkungan, modelling, dan faktor frustasi (Krahe, 2005).

Kelima subjek ketika berada disekolah menunjukkan perilaku sering clometan (berkata tidak sopan kepada guru ketika pelajaran), menjahili teman, mengambil barang milik temannya, membolos sekolah, merokok di sekolah, berani kepada guru dan sering melanggar peraturan di sekolah. Perilaku yang seperti ini terutama dilakukan kepada teman yang lebih pendiam darinya atau yang tidak termasuk dalam geng mereka. Perilaku mereka yang seperti ini dilatar belakangi oleh beberapa faktor yaitu, faktor pola asuh atau adanya gap antara orang tua dan anak dan berdampak pada pola komunikasi, faktor lingkungan, modelling dan faktor frustasi.

Kelima subjek merupakan anak dari keluarga menengah kebawah, dimana orang tua mereka bekerja sebagai seorang buruh yang setiap harinya bekerja dari pagi sampai malam. Kurangnya pengawasan dan kasih sayang yang diberikan oleh orang tua kepada anaknya membuat pola komunikasi dalam keluarga menjadi minim dan anak memilih untuk mencari tempat pelarian untuk melampiaskan emosinya. Selain itu pola asuh yang salah (otoriter dan permisive) dan latar belakang keluarga yang broken home semakin memperkuat perilaku subjek. Lingkungan tempat mereka tinggal juga berdampak pada perilaku mereka. Berada pada lingkungan yang kurang sehat membuat mereka melihat kemudian meniru apa yang ada di lingkungan tempat tinggalnya dan berpengaruh pada perilaku subjek saat ini yaitu agresif.

Perilaku terbentuk karena pembelajaran dari lingkungan sekitarnya, melalui pengalaman langsung atau mengamati perilaku orang lain disekitarnya demikian juga dengan perilaku agresi merupakan perilaku yang terbentuk karena faktor tersebut sehingga perlu adanya program pelatihan atau intervensi untuk menurunkan perilaku agresi tersebut. Bringham (1991) ada tiga faktor yang mempengaruhi perilaku agresi yaitu (1) proses belajar, (2) penguatan (reinforcement) dan (3) imitasi peniruan terhadap model.

Sears, dkk. (1988) menyatakan bahwa perilaku biasanya merupakan reaksi yang dipelajari karena adanya penguat atau reinforcement. Perilaku dapat terbentuk karena pembelajaran melalui imbalan dan ganjaran. Jika efek perilaku adalah negatif maka dapat menurunkan 
perilaku tersebut. Perilaku agresi dapat menimbulkan efek yang negatif maka dengan pelatihan yang diberikan diharapkan dapat menurunkan perilaku agresi pada anak dengan penerapan metode imbalan atau ganjaran baik dengan verbal maupun non-verbal sebagai penguat untuk menurunkan perilaku agresi.

Behaviorisme memandang bahwa pada dasarnya manusia tidak membawa bakat apa-apa untuk menciptakan sebuah perilaku agresif. Perilaku agresif yang muncul pada manusia berkembang berdasarkan stimulus yang diterima dari lingkungan sekitar tempat mereka hidup (Prawira, 2014). Ketika manusia hidup pada lingkungan yang buruk, seperti sering melihat tindak kekerasan akan menghasilkan manusia yang berperilaku keras dan buruk. Sebaliknya, ketika manusia hidup di lingkungan yang baik, seperti hidup dimana banyak diberikan kasih sayang akan menghasilkan manusia yang lembut dan baik. Berangkat dari pernyataan pandangan behaviorisme dapat disimpulkan bahwa perilaku agresif dapat muncul tergantung dengan stimulus yang diterima oleh manusia tersebut yangberasal dari lingkungannya.

Mereka tinggal di lingkungan keluarga yang kurang adanya perhatian dan kasih sayang dari orang tua dan lingkungan pertemanan yang memberikan dampak negatif kepada subjek. Karena merasa tidak mendapatkan perhatian dan kasih sayang dari orang tua membuat para subjek menjadi lebih dekat dengan teman-temannya dan membuat perilakunya sama dengan teman-temannya. Karena merasa kurang memiliki kasih sayang dan perhatian dari orang tua yang membuatnya harus menyimpan permasalahannya sendirian, maka mereka akan mengalihkannya dengan mencari mencari masalah dan perhatian di sekolah yang dianggap dapat meredakan permasalahannya dan untuk meluapkan emosinya. Perilaku tersebut menghasilkan kepuasan untuk subjek maka perilaku tersebut diulang-ulang. Kondisi lingkungan sekitar subjek sangat berpengaruh pada perilaku subjek saat ini. Hal ini menunjukkan kurangnya kemampuan subjek dalam melakukan manajemen diri atau kontrol diri untuk mengendalikan emosi serta dorongan-dorongan dalam dirinya sehingga intervensi self management diperlukan untuk mengurangi perilaku agresif subjek.

\section{Diagnosis dan Prognosis}

Berdasarkan hasil asesmen yang telah dilakukan subjek mempunyai permasalahan perilaku agresif. Terapis memperkirakan keberhasilan dalam intervensi kelompok adalah positif. Hal ini disebabkan keseluruhan subjek memiliki keinginan untuk berubah menjadi lebih baik. Dengan permasalahan yang sama keseluruhan subjek mampu kooperatif dan menjalin dukungan serta kerja sama yang baik dalam pelaksanaan terapi sehingga hal ini memperkuat prognosis yang baik bagi keseluruhan subjek. Selain itu sikap lingkungan subjek yang terbuka terhadap informasi serta mau terlibat untuk memberikan dukungan terhadap perubahan subjek.

\section{Intervensi}

Intervensi yang digunakan untuk mengurangi perilaku agresif verbal subjek adalah self management. Self-management adalah suatu proses di mana terapis mengarahkan perubahan tingkah laku mereka sendiri, dengan menggunakan satu strategi atau kombinasi strategi. Self management atau disebut juga modifikasi diri merupakan sebuah strategi yang menggunakan prinsip-prinsip analisis behavioral untuk mengubah atau mengontrol perilaku diri sendiri (Martin \& Pear, 2015). Dalam menggunakan prosedur self management, terapis mengarahkan usaha perubahan dengan mengubah aspek-aspek lingkungannya atau dengan mengatur konsekuensi.

Target intervensi self management adalah untuk mengurangi perilaku agresi verbal subjek. Perilaku agresif adalah tindakan permusuhan yang nyata atau ancaman permusuhan, biasanya tidak ditimbulkan oleh orang lain, diekspresikan berupa penyerangan secara fisik atau lisan terhadap pihak lain (Hurlock, 2005). Sebelum penerapan self management, subjek diberikan 
penjelasan tentang intervensi yang akan diberikan untuk meningkatkan kepedulian kepada subjek dan berkomitmen untuk mengikuti intervensi samapai selesai. Berikut adalah penjelasan pada masing-masing sesi dalam penerapan self management.

Sesi 1: Spesifikasi masalah dan penetapan tujuan. Menetapkan perilaku bermasalah yang akan diintervensi yaitu perilaku subjek yang agresi verbal. Tujuan program untuk mengurangi perilaku agresi verbal subjek. Sesi ini berjalan lancar, dimana para subjek terlihat merespon apa yang sudah disampaikan oleh terapis. Dalam sesi ini terapis bersama dengan subjek menetapkan permasalahan yang akan ditangani, dan telah dikomunikasikan bersama bahwa target perilaku yang akan diubah adalah perilaku agresif mereka.

Sesi 2: Membangun komitmen. Subjek membuat daftar keuntungan apa saja yang ia peroleh bila perilaku bermasalahnya berubah, berkomitmen terhadap diri sendiri untuk mampu melakukan perubahan diri dan menyampaikan kepada orang-orang terdekat tentang komitmennya.

Sesi 3: Analisis penyebab terjadinya masalah. Mengidentifikasi penyebab munculnya perilaku agresif. Sesi ini berjalan lancar, dimana masing-masing subjek dapat memberikan argumentasi. Pada sesi ini para subjek mampu menganalisis dan menyampaikan kepada terapis apa yang melatar belakangi perilaku mereka. Faktor yang membuat mereka berperilaku agresif adalah faktor lingkungan, yaitu lingkungan keluarga dan didukung juga oleh faktor pertememanan sehingga memicu perilaku subjek yang seperti ini.

Sesi 4: Desain implementasi program. Merancang jadwal aktivitas yang disepakati subjek dalam penerapan intervensi. implementasi program terdiri dari self talk dan modelling. Pada sesi ini, terapis bersama dengan subjek merancang aktifitas atau target perilaku apa yang akan mereka capai selama intervensi berlangsung. Jadwal aktivitas yang dibuat ini sebagai upaya untuk melihat kemajuan dari intervensi. Aktifitas yang dilakukan oleh subjek ini tentunya untuk meningkatkan kontrol diir agar subjek bisa menahan keinginannya untuk berperilaku agresif.

Selain itu mereka juga diajari bagaimana melakukan self talk ketika keinginan berperilaku agresif itu muncul. Modelling juga diberikan untuk memberikan contoh yang baik agar para subjek bisa merubah perilakunya seperti model yang diberikan. Model yang digunakan dalam modelling ini adalah teman mereka sendiri yang terkenal baik dan pintar di sekolah.

Sesi 5: Implementasi program. Subjek menjalankan aktivitas yang telah dibuat sebelumnya. Pada sesi ini subjek mulai melakukan aktifitas yang telah dibuat. Subjek diminta untuk mengimplementasikan apa yang sudah dibuat di lingkungan sekolah. Karena dilingkup sekolah inilah mereka lebih sering berinteraksi, entah dengan guru atau teman-temannya.

Sesi 6: Evaluasi I. Memeriksa dan mendisuksikan perubahan perilaku mereka dan pemberian feedback serta motivasi untuk melanjutkan implementasi program. Dalam sesi ini, para subjek menyadari bahwasan perilaku agresif bukan perilaku yang baik namun sudah menjadi kebiasaan sehingga agak susah untuk diubah. Mendengar ucapan para subjek, kemudian terapis memberikan motivasi kepada mereka bahwa untuk mengubah suatu perilaku yang sudah menjadi kebiasaan memang sulit, namun bukan berarti tidak bisa. Motivasi diberikan agar para subjek tidak berputus asa dalam menjalankan terapi.

Sesi 7: Evaluasi II. Evaluasi kedua setelah implementasi program dengan prosedur yang sama dengan sesi keenam. Pada sesi ini, para subjek sudah mulai menunjukkan perubaha. Dimana mereka sudah bisa mengendalikan emosi mereka untuk tidak berperilaku agresif. Ketika seseorang berperilaku agresif kepadanya mereka hanya tertawa dan diam serta seakan-akan tidak setuju dengan perkataan mereka. Kemudian ketika mereka mereka merasa ingin membalas, mereka melakukan self talk yaitu mengingat bahwa perilaku agresif sebaiknya tidak dilakukan karena tidak bermanfaat dan apa yang dilakukan temannya kepada mereka merupakan suatu 
bentuk candaan dan suatu bentuk keakraban sesama teman, sehingga tidak bermaksud mengumpat.

Sesi 8: Terminasi dan mencegah relapse. Pemberian feedback tentang kinerjanya selama implementasi program, mengakhiri program dan memastikan subjek berkomitmen menerapkan program dalam kehidupan sehari-hari terlepas dari intervensi melalui kontrak perilaku.

Follow up. Evaluasi perubahan perilaku agresi dalam 1 minggu pasca intervensi dengan melakukan wawancara dan observasi terhadap subjek.

\section{Hasil dan Pembahasan}

\section{Hasil}

Hasil intervensi menunjukkan adanya penurunan perilaku agresif yang dilakukan oleh subjek. perubahan yang di alami subjek dievaluasi menggunakan Agression Scale (Buss \& Perry, 1992) dan menggunakan observasi berdasarkan ceklist perilaku yang telah dibuat sebelumnya. Pemberian angket tersebut bertujuan untuk mengetahui skor perilaku agresif pada siswa, sedangkan ceklist observasi digunakan untuk melihat frekuensi subjek dalam melakukan agresif selama di sekolah. Keduanya digunakan untuk melihat kemajuan intervensi selama sebelum dan sesudah diberikan konseling kelompok self-management. Adapun hasil perbedaan pre-test dan post-test yang digambarkan dalam Gambar 1.

Berdasaran Gambar 1, diketahui bahwa secara keseluruhan dapat dilihat adanya perbedaan grafik hasil pre-test yang lebih tinggi daripada hasil post-test pada masing-masing subjek. Hal ini menunjukkan bahwa adanya penurunan skor perilaku agresif pada subjek antara sebelum dan sesudah diberikan perlakuan konseling kelompok dengan menggunakan strategi self-management.

Selain dievaluasi menggunakan skala agresi, keberhasilan intervensi juga dapat dilihat berdasarkan ceklist observasi perilaku agresi subjek yang dilakukan sebelum dan sesudah dilakukannya konseling kelompok dengan menggunakan strategi self management. Berdasarkan hasil pengamatan yang dilakukan oleh terapis dimana sebelum diberikan intervensi dan sesudah intervensi menunjukkan bahwa subjek mengalami perubahan perilaku. Tampak perubahan perilaku subjek dimana sebelumnya sering celometan saat guru menerangkan, sering mengumpat, memanggil teman dengan nama julukan,sering memaki teman, berkata kotor dan sering menjahili teman. Namun setelah diberikan intervensi subjek bisa merubah perilakunya yaitu ketika guru menerangkan tidak lagi celometan, tidak mengumpat, memanggil teman sesuai dengan namanya, tidak memaki teman, tidak berkata kotor, dan tidak lagi menjahili temannya.

\section{Pembahasan}

Berdasarkan hasil intervensi dan hasil post-test yang dilakukan pada subjek, dapat dikemukakan bahwa terjadi perubahan dan penurunan perilaku agresif pada subjek setelah mengikuti intervensi. Ini berarti program intervensi konseling kelompok dengan teknik self management efektif untuk mengurangi perilaku agresif pada subjek. Hasil penelitian ini sesuai dengan pernyataan Denson, DeWall \& Finkel (2012) \& Baker., et al. (2016) bahwa self management merupakan intervensi yang dapat digunakan untuk mengurangi perilaku agresif.

Perilaku terbentuk karena pembelajaran dari lingkungan sekitarnya, melalui pengalaman langsung atau mengamati perilaku orang lain disekitarnya demikian juga dengan perilaku agresi merupakan perilaku yang terbentuk karena faktor tersebut sehingga perlu adanya program pelatihan atau intervensi untuk menurunkan perilaku agresi tersebut. Bringham (1991) ada tiga faktor yang mempengaruhi perilaku agresi (1) proses belajar, (2) penguatan (reinforcement) dan (3) imitasi peniruan terhadap model.

Salah satu intervensi yang dapat digunakan untuk mengurangi perilaku agresif yaitu self management. Dimana self management ini dapat memberikan perubahan positif 


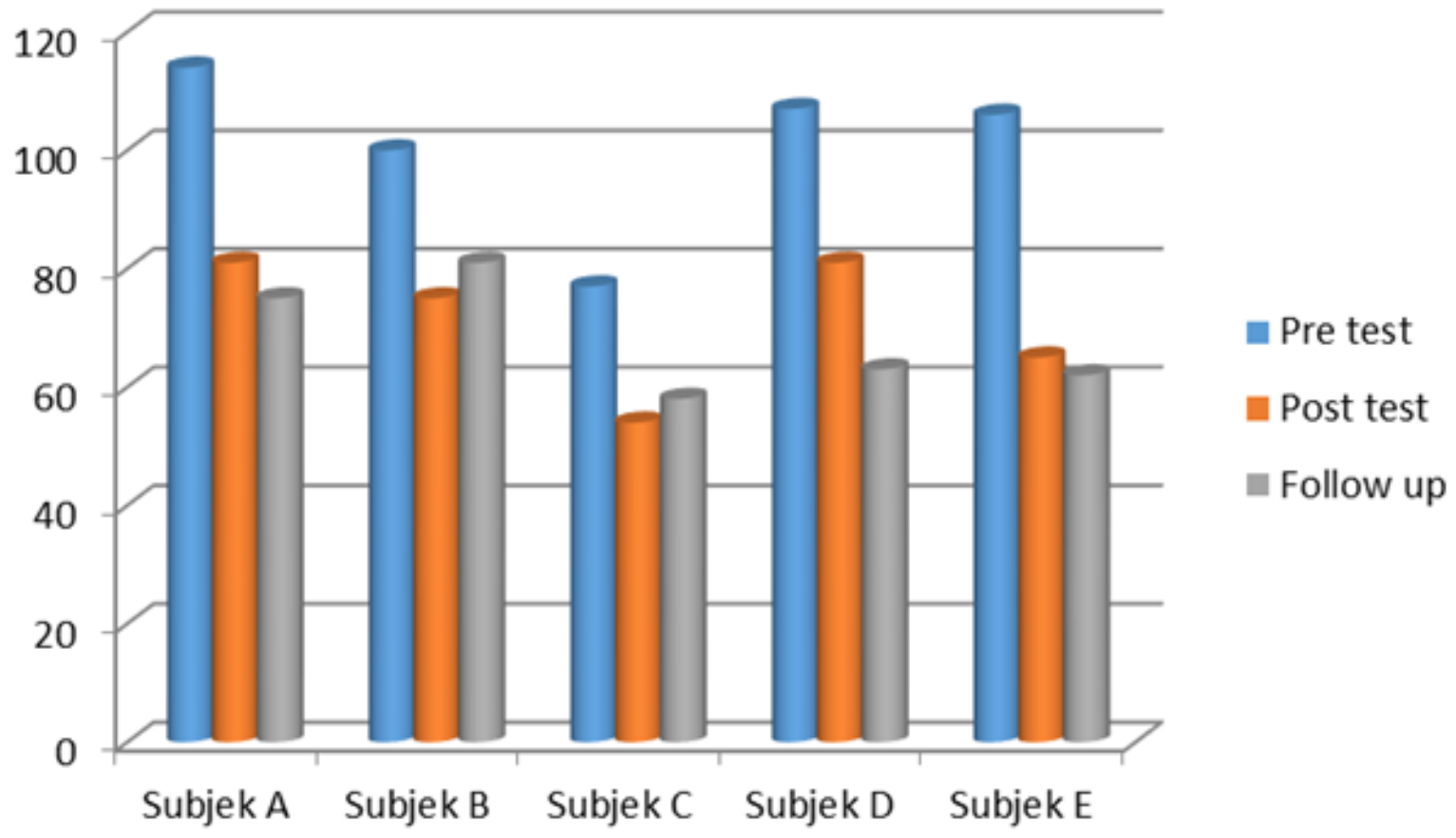

Gambar 1. Perubahan Perilaku Agresif Sebelum dan Sesudah Intervensi.

terhadap perilaku agresif karena penentuan target perilaku atau aktivitas secara realistis dan adanya penguatan (reinforcement) terhadap perubahan yang sesuai dengan target. Operant conditioning menjadi dasar teori yang tepat untuk menjelaskan self management melalui penguatan dapat meningkatkan atau mengurangi frekuensi perilaku agresif. Terbentuknya perilaku menurut Skinner (dalam Olson \& Hergenhahn, 2011) bergantung pada konsekuensi-konsekuensi yang mengikuti perilaku tersebut dan individu cenderung mempertahankan suatu perilaku bila terdapat konsekuensi yang menyenangkan bagi dirinya atas perilaku tersebut.

Dari hasil observasi dan evaluasi yang dilakukan telah terjadi penurunan perilaku agresif pada subjek. Berdasarkan hasil tersebut dapat dikatakan bahwa konseling kelompok dengan teknik self management mempunyai dampak yang baik dan memiliki peranan yang penting di dalam mengurangi perlaku agresif pada subjek.

\section{Simpulan}

Setelah pemberian perlakuan konseling kelompok dengan teknik self management terdapat perbedaan skor antara pre-test, post-test dan follow up pada perilaku agresif subjek. Oleh sebab itu dapat disimpulkan bahwa ada perbedaan yang signifikan pada skor perilaku agresif siswa antara sebelum dan sesudah pemberian konseling kelompok dengan teknik self management.

\section{Referensi}

Atkinson, Rita L.( 2001). Pengantar Psikologi II. Jakarta: Erlangga.

Baker, E. A., Klipfel, K. M., \& van Dulmen, M. H. M. (2016). Self-Control and Emotional and Verbal Aggression in Dating Relationships. Journal of Interpersonal Violence, 088626051663606. doi:10.1177/0886260516636067 Baron R.A. \& Byrne D. B., (1988). Social Psychology, Haughton Mifflin Company, Boston. 1994 Koeswara, E., Agresi Manusia, Cet 1, PT Eressco, Bandung.

Baron R.A. \& Byrne D. B. (1994). Social Psychology, Haughton Mifflin Company, Boston.

Baron, R. A \& Byrne, D. (2004). Psikologi Sosial. Edisi 10. Jakarta: Erlangga

Berkowitz, L. (2003). Agresi 1, Jakarta: Pustaka Binaman Pressindo.

Berkowitz, L. (2005). Aggresion: Itscauses, consequences, and control. NewYork: Mc Graw-Hill. 
Buss, A.H. \& Perry, M. 1992. The Aggression Questionnaire. Journal of Personality and Social Psychology. 63, (33), 452-459.

Brigham, J. C. (1991). Social Psychology, Harper Collins Publishers. Inc., New York.

Clerq, L.D. (1994). Tingkat laku abnormal dari sudut pandang perkembangan. (Terjemahan: Santoso). Jakarta: PT. Grasindo.

Gunarsa, S. D. (2004). Dari Anak Sampai Usia Lanjut : Bunga rampai psikologi perkembangan. Jakarta: Gunung Mulia

Hurlock, Elizabeth B. (1980). Psikologi Perkembangan Suatu Pendekatan Sepanjang Rentang Kehidupan. Jakarta: Erlangga.

Hurlock, E.B. (2003). Psikologi Perkembangan. Jakarta: Erlangga

Koeswara, E. (1988). Agresi Manusia, Cet 1, PT Eressco, Bandung.

Krahe, B. (2005). Perilaku Agresif. Yogyakarta: Pustaka Belajar

Martin, G., \& Pear, J. (2015). Modifikasi Perilaku: Makna dan Penerapannya (edisi ke-10). Yogyakarta: Pustaka Pelajar

Ninness, H. A. C., Ellis, J., Miller, W. B., Baker, D., \& Rutherford, R. (1995). The Effect of a Self-Management Training Package on the Transfer of Aggression Control Procedures in the Absence of Supervision. Behavior Modification, 19(4), 464-490. doi:10.1177/01454455950194004

Olson, M.H., \& Hergenhahn, B.R. (2011). Pengantar Teori-Teori Kepribadian (Edisi ke-8). Yogyakarta: Pustaka Pelajar

Prawira, Purwa Atmaja. (2014). Psikologi Kepribadian dengan Prespektif Baru. Jogjakarta: Ar-Ruzz Media Santrock, J. W. (2003). Life-Span Development: Perkembangan masa-hidup. Jakarta: Erlangga.

Sears D., Peplan, L. A., Freeman, J. L., Taylor \& Shelley. E.(1988) Social Psychology, Englewood Cliffs, Prentice Hall Inc.

Sobur, Alex. (2003). Psikologi Umum. Bandung: Penerbit Pustaka Setia

Soemanntri, Sutjihati. (2006). Psikologi Anak Luar Biasa. Bandung: PT Refika Aditama. 